\title{
A shift Paradigm of Consumer towards online shopping
}

\author{
Dr. Vipin Kumar* \& Kadambini Kumari** \\ Organization: L.N.Mishra College of Business Management, Muzaffarpur, Bihar \\ Organization: Indira School of Business Studies, Pune
}

\begin{abstract}
Shopping has paradigm shift due to the influence of technology with most people preferring online shopping to the traditional physical store shopping. This research aims to understand the comparison between online shopping \& physical shopping. Refer to study the Shifting of consumer behavior towards these modes of shopping compare towards other shopping mode like physical shopping mode which was trend in past. This paper identified that male population tend to shop more online shopping rather than physical shopping compare to female but there is no significance between gender \& shopping mode. Physical Buying is preferred due to faith of the people about the transition of money \& product physically. People are slowly going for online shopping preference but the majority of people go to physical shopping as it is having trust, feel and touch of the product. In the research outcome says that flipkart and jabong are the major players in the online retail and online shopping compare to other mode in the Bihar Region \& this trend is going to increase further in future.
\end{abstract}

Keywords: Consumer Behaviour; Online Shopping;Physical Shopping

\section{Introduction}

Consumer behaviour is the study of individuals, groups, or organizations and the processes they use to select, secure, and dispose of products, services, experiences, or ideas to satisfy needs and the impacts that these processes have on the consumer and society. Shopping is no more the need only, it is the experience which can be inrich by adding advantages like availibility, time cost $\&$ benefits of choice $\&$ comfort.People life is changing with the greater pace then the change in the advertisement on TV Channel. People want's everything to minimum easse of the finger clik \& that is provided by the onlineshopping. Change is already taking place in mode of selection $\&$ online shopping will become the $1^{\text {st }}$ choice soon.

This study is expected to improve our understanding of online and physical consumer behaviour.Internet $\&$ online safty mode purchasing still take a place in people desktop. People are intend to try new things \& like to be noticed as early adopter of technology advancement .

\section{Literature Review}

(Wen, Ivan Jul-Sep2013)Study was carried out to find the impact of three attributes (perception of convenience, perception of merchandise options, and perception of value) on online shopping which can be valid for the research study carried out $\mathrm{n}$ this prospective also to compare the penetration of online shopping.(Floh, Arne , Koller, Monika, Zauner, Alexander, April 2013) The study results on finding three parameters for evaluating the choice on consumers sharing experience through reviews after experiencing. The positive reviews always impact the decision for selection. (Liu, Xia, Burns, Alvin C , Hou, Yingjian, 2013)price-conscious user are more intend to do online shopping due to discounting offers available but in contrast to this consumers like to see product personally are more intend to do physical shopping.(Gehrt, Kenneth C.Rajan, Mahesh N.Shainesh, G.Czerwinski, David,O'Brien, Matthew, 2012)Consumers are categories on the three parameters for the selection of the mode of shopping. Quality at any price and reputation/recreation are more inclining to do online shopping. Adverse to this value singularity are intend toward physical shopping.(Jifeng Luo,Sulin Ba, Han Zhang, 2012) Research was carried to find the satisfaction for online shopping but result says that satisfaction after shopping is still low. a retailer's service quality, website design, and pricing play important roles whereas for physical shopping is preferred due to problems in online shopping on low retailer visibility and high product uncertainty.

(Jiang, Ling (Alice, Yang, Zhilin, Minjoon Jun, 2013) The research was carried to find the motivational factor for online shopping \& result says that convenience of shopping plays very important role for decision of online shopping. (Nirmala, Ratih Puspa,Dewi, Ike Janita, April 2012) The research was carried to identify the trends of online shopping \& it was observed that fashion products are popular product range \& Y Generation ranging aged between 15 and 30 years are likely to do more online shopping. The surprised finding was that male are more intend to do online shopping then female online.

\section{OBJECTIVES OF THE STUDY}

- To compare between online shopping \& physical store shopping. 
- To understand which is the most preferred mode of shopping and also to understand what criteria customers look into while selecting the mode for shopping

- Factor Influencing the decision of online purchasing

- To list the Advantages \& disadvantages according to the consumer Percetion about diifent type of Purchasing

\section{HYPOTHESIS}

1. H0: Gender don't significantly impact the choice of mode of shopping.

Ha: Gender significantly impact the choice of mode of shopping.

2. H0: Online website popularity does not significantly impact the preference of shopping for the customer

Ha: Online website popularity does significantly impact the preference of shopping for the customer

3. H0-Price Discounting does not significantly impact consumer behavior towards online Shopping

4. Ha: Price Discounting does significantly impact consumer behavior towards online Shopping

\section{Research Methodology}

The primary objective of this paper is to do comparative study of online shopping and physical store shopping.

i)Research Design: It is Descriptive Research as it a analysis the Resaersh problem to find the preferences of the people for online shopping

ii)Sampling Design:

Universe: All Individual does online shopping

Sample Frame: Patna

Sample units: Each individual does online shopping

Type of Sampling: Convinece Shoppling

Sampling Size: This study is based on the sample of 100 respondents.

\section{DATA COLLECTION}

The type of method followed for data collection is primary data collection, as questionnaire was prepared \& flotted online by using online webbased tool.

\section{DATA INTERPRETATION AND ANALYSIS}

i)Gender:

\begin{tabular}{|l|l|}
\hline & Gender \\
\hline Male & 81 \\
\hline Female & 19 \\
\hline
\end{tabular}

\section{Gender}

Male Female

\section{$19 \%$}

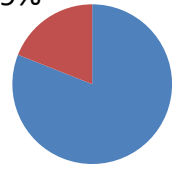

IV.

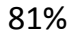

From the figures it is evident that online shopping is preferred more by the male population compared to their female in Patna.

ii) Income:

\begin{tabular}{|l|l|}
\hline Per Month Income & Percentage \\
\hline $10,000-20,000$ & $38 \%$ \\
\hline $20,000-30,000$ & $42 \%$ \\
\hline $30000-40000$ & $12 \%$ \\
\hline above 40000 & $8 \%$ \\
\hline
\end{tabular}




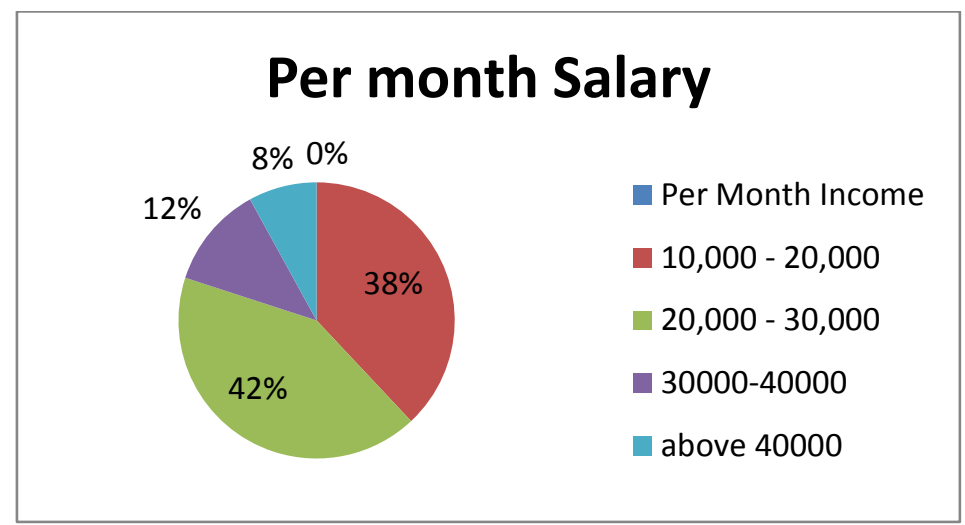

People with the salary range of 10000-30000 prefer to shop online.This mode of shopping is not very popular among high income groups may be they are prefering shopping physically.

iii) Preference:

\begin{tabular}{|l|l|}
\hline Shopping Preference & \% \\
\hline Online & $11 \%$ \\
\hline Store & $72 \%$ \\
\hline Both & $17 \%$ \\
\hline
\end{tabular}

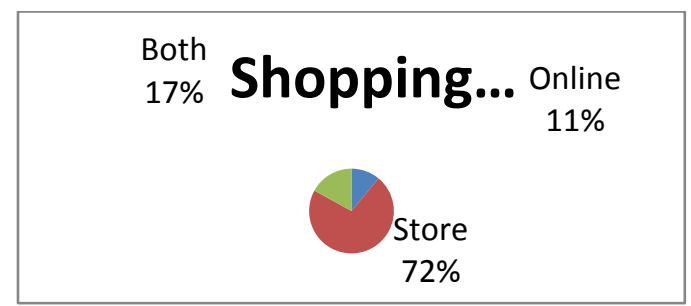

$72 \%$ of the people prefer to do Physical shopping followed by online as well as physical shopping with $17 \%$ followed by online shopping indicating that online shopping is least prefer still in patna.

iv) Time Duration (Online shopping):

\begin{tabular}{|l|r|}
\hline Less than a year & $43 \%$ \\
\hline 1 to 2 years & $32 \%$ \\
\hline $2-3$ years & $17 \%$ \\
\hline More than 3 years & $8 \%$ \\
\hline
\end{tabular}

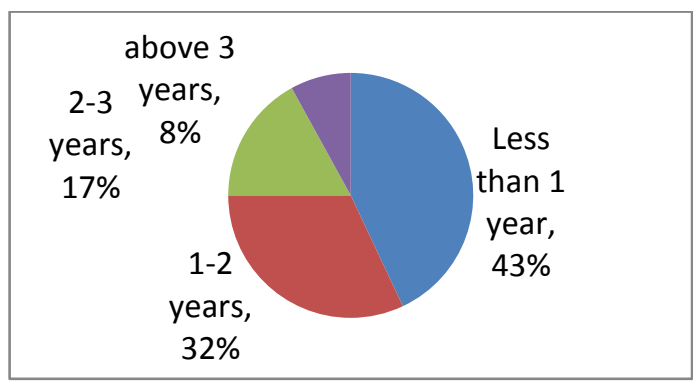

Out of the 28 respondents who shop online, $43 \%$ of people have been shopping online for less than a year whereas the number of people shopping online for more than a year is quite small which indicates that online shopping has gained popularity recently. 
v)Time Duration (Physical Shopping):

\begin{tabular}{|l|r|}
\hline Spot Shopping duration & $\%$ \\
\hline less than 1 year & $7 \%$ \\
\hline $1-2$ years & $17 \%$ \\
\hline $2-3$ years & $21 \%$ \\
\hline above 3 years & $55 \%$ \\
\hline
\end{tabular}

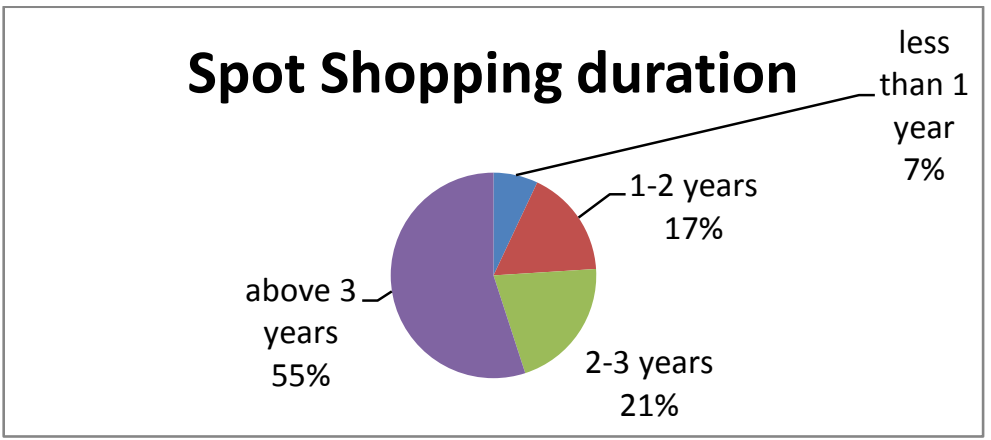

$55 \%$ of people out of 89 have been doing physical store shopping for more than 3yrs so majority have been engaged in physical store shopping.

vi) Willingness to Recommend:

\begin{tabular}{|c|c|}
\hline $\begin{array}{l}\text { willingness to } \\
\text { recommend }\end{array}$ & $\%$ \\
\hline Yes & $54 \%$ \\
\hline No & $22 \%$ \\
\hline Cant Say & $24 \%$ \\
\hline
\end{tabular}

\section{willingness to...}

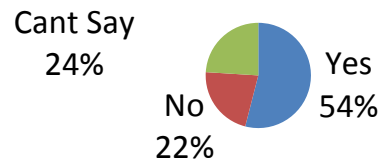

$54 \%$ of people out of the 28 who have shopped online would recommend it to others which shows most people favour online shopping and must have had a positive experience shopping online.

vii) Product wise preferences

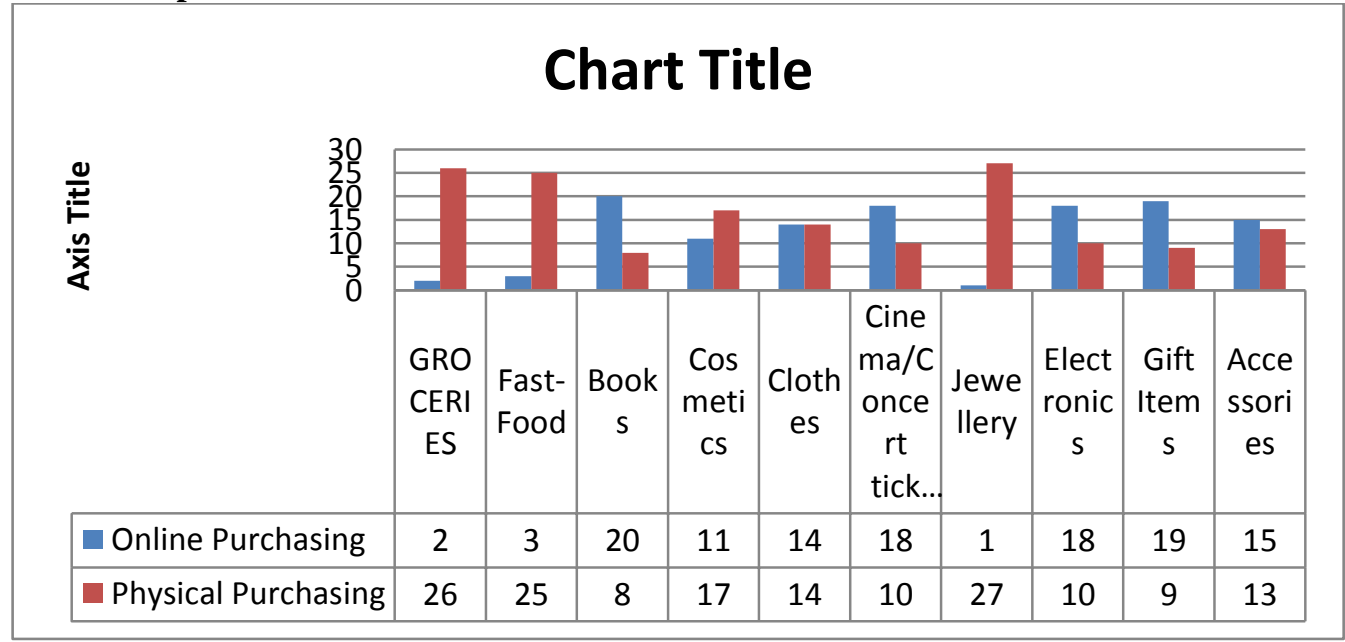




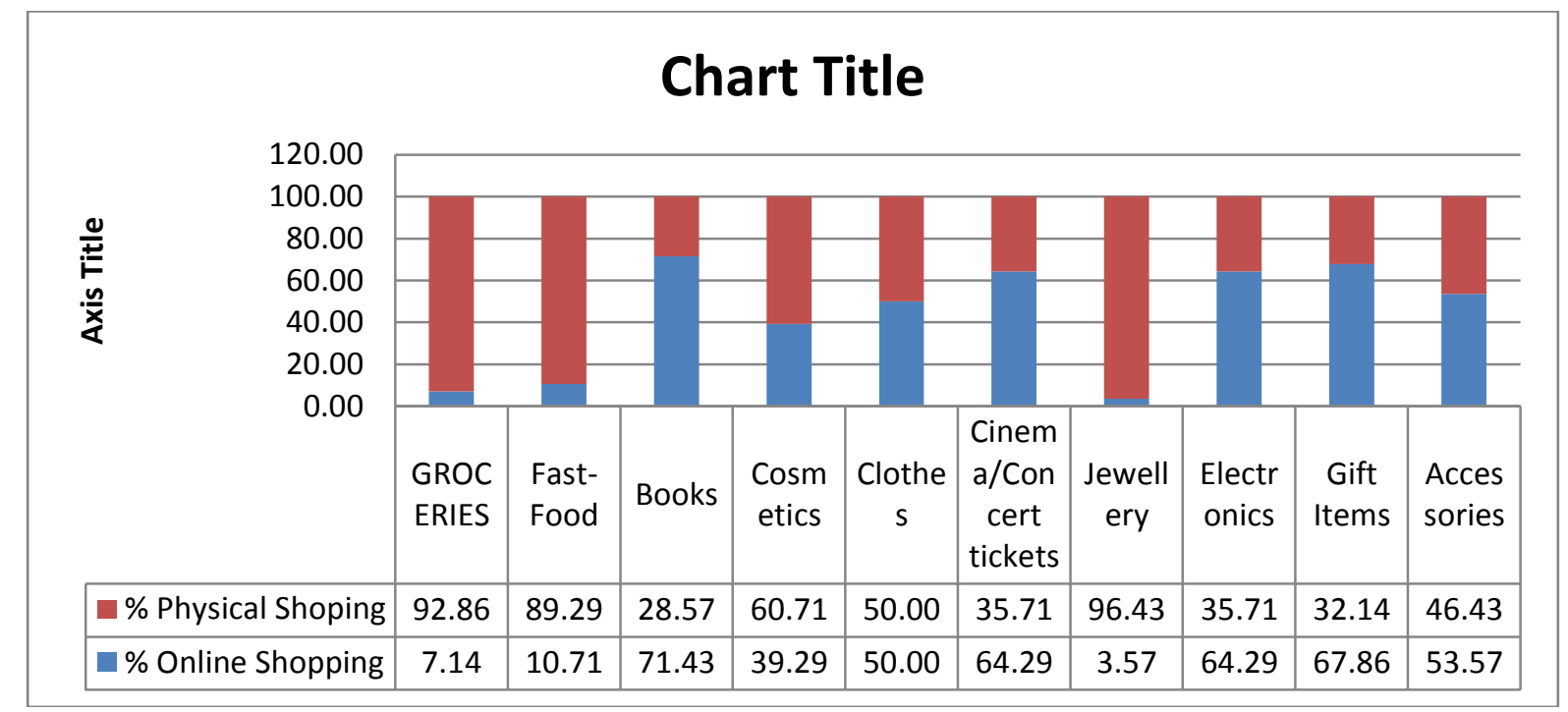

Online Buying is popular in Books, Clothing, Cinema/Concert Tickets, Electronics, Gifts \& Accessories item with more than $50 \%$ preference for online shopping by the people else Groceries, Fast food, Cosmetics, Jewellery purchasing still popular by physical purchasing mode.

viii) Online store/website popularity

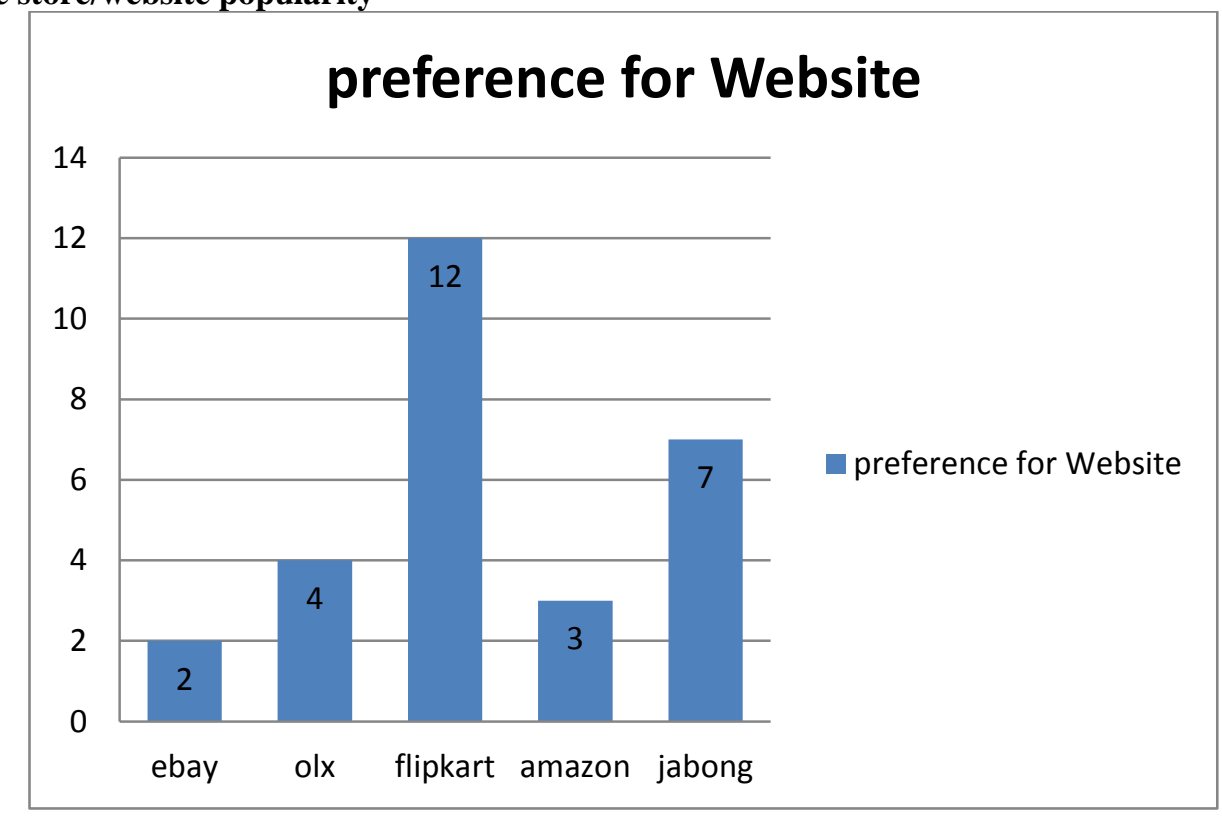

Flipkart \& Jabong are the popular site as $12 \& 7$ members are prefering out of 28 online buyer.

ix) Reasons for online shopping preference

\begin{tabular}{|l|r|}
\hline & \% Reasons of online purchasing \\
\hline Price discount & 38 \\
\hline Branding & 32 \\
\hline time save & 4 \\
\hline accessibility/availability & 24 \\
\hline Friend references & 2 \\
\hline \multicolumn{2}{|l}{} \\
\hline
\end{tabular}




\section{\% Reasons of online purchasing}

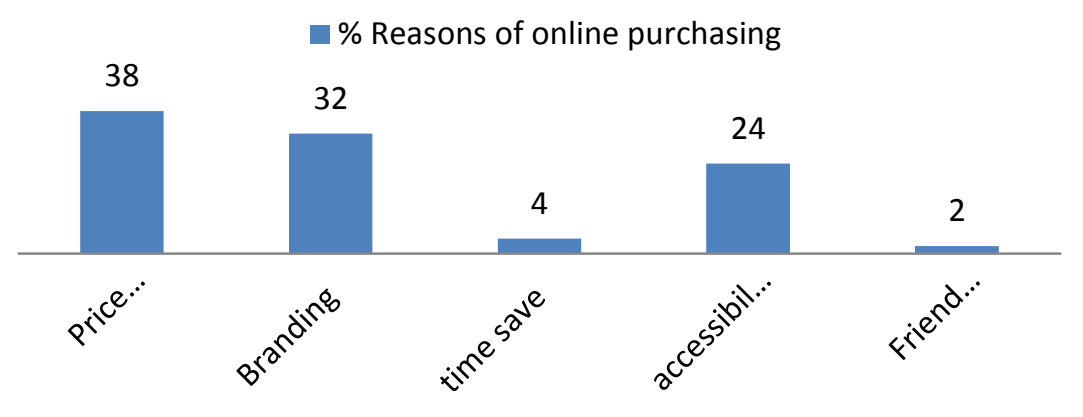

Price discounting, Brand accesability \& avaliability are the main attraction of the online shopping as $38 \%, 32 \%$ $\& 24 \%$ preference by people

x) Reasons for Physical shopping preference

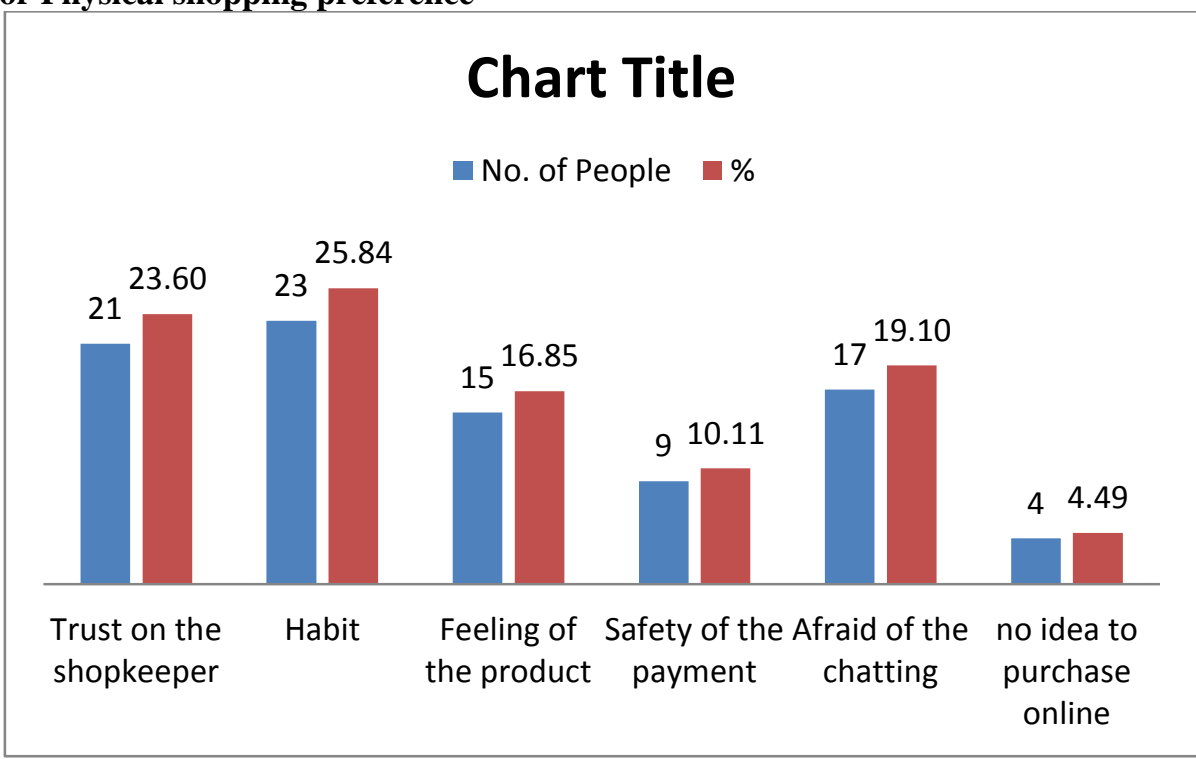

Trust, Habit of Purchasing, feeling of the product, payment safty, resistance to get safety while online payment are the reasons for physical purchasing with $24 \%, 26 \%, 17 \%, 10 \% \& 19$ resdectively

\section{CHI-SQUARE TEST}

We performed the chi-square test to check the correctness of hypothesis

Test for Hypothesis 1:

H0: Gender don't significantly impact the choice of mode of shopping.

Ha: Gender significantly impact the choice of mode of shopping.

\begin{tabular}{|c|c|c|c|}
\hline & $\begin{array}{l}\text { Online } \\
\text { Purchasing }\end{array}$ & $\begin{array}{l}\text { Physical } \\
\text { Purchasing }\end{array}$ & Total \\
\hline Male & 10 & 56 & 66 \\
\hline Female & 2 & 32 & 34 \\
\hline Total & 12 & 88 & \\
\hline & Observed & Expected & Deviation \\
\hline Male online Purchased & 10 & 9.72 & 0.058 \\
\hline Male not online Purchased & 56 & 71.28 & -0.429 \\
\hline
\end{tabular}




\begin{tabular}{|c|c|c|c|c|c|}
\hline Female Online Purchased & 2 & 2.28 & -0.246 & & \\
\hline Female Not Online Purchased & 32 & 16.72 & 1.828 & & \\
\hline & & & Chi Sq & 1.211 & \\
\hline & & & df & 1.000 & $\begin{array}{l}\text { No. of } \\
\text { Categories } \\
\text { minus } 1\end{array}$ \\
\hline Total Male & 81 & & Chitest: P Value & 0.271 & \\
\hline Total Female & 19 & & & & \\
\hline Total who Purchase Online & 12 & & & & \\
\hline Total who not purchase online & 88 & & & & \\
\hline Total & 100 & & & & \\
\hline
\end{tabular}

Calculated Value is much higher than the Standard value .05 there for Null Hypothesis Accepted, there for Alternate hypothesis rejected. There is no significant impact of gender on Purchasing Mode decision.

\section{Test for Hypothesis 2:}

H0: Online website popularity does not significantly impact the preference of shopping for the customer

Ha: Online website popularity does significantly impact the preference of shopping for the customer

\begin{tabular}{|l|r|r|r|}
\hline & Choice of Website & Not to chose & Total \\
\hline A Popular Website & 18 & 6 & 24 \\
\hline Not a Popular website & 2 & 2 & 4 \\
\hline Total & 20 & 8 & \\
\hline
\end{tabular}

\begin{tabular}{|l|r|r|r|}
\hline & Observed & \multicolumn{2}{c|}{ Expected } \\
\hline Popular Website chosen & 18 & 17.143 & 0.1 \\
\hline Popular website not chosen & 6 & 6.857 & -0.25 \\
\hline Not Popular Website chosen & 2 & 2.857 & -0.6 \\
\hline Not Popular website not chosen & 2 & 1.143 & 1.5 \\
\hline
\end{tabular}

\begin{tabular}{|l|r|l|r|l|}
\hline Selection of popular Website & 24 & Chi Sq & 10.85714286 & \\
\hline Selection of Not Popular Website & 4 & $\mathrm{df}$ & $\begin{array}{l}\text { No. of } \\
\text { Categories } \\
\text { minus 1 }\end{array}$ \\
\hline Choice of Website & 20 & Chitest: P Value & $\mathbf{0 . 0 0 0 9 8 4 1 5 4}$ & \\
\hline Not to choose website & 8 & & & \\
\hline & & & & \\
\hline Total & 28 & & & \\
\hline
\end{tabular}

Calculated Value is much lower than the Standard value .05 there for Null Hypothesis Rejected, therefor alternate hypothisis accepted. Online website popularity significantly impact the selection of the website for online shopping. 
Test for Hypothsesis 3:

1. H0-Price Discounting does not significantly impact consumer behavior towards online Shopping

2. Ha: Price Discounting does significantly impact consumer behavior towards online Shopping

\begin{tabular}{|l|r|l|}
\hline & $\begin{array}{l}\text { Online Purchasing } \\
\text { Preference }\end{array}$ & $\begin{array}{l}\text { Not having preference } \\
\text { for online Purchasing }\end{array}$ \\
\hline Online Price discounting offer & 11 & 17 \\
\hline No online Price discounting offer & 8 & 20 \\
\hline
\end{tabular}

\begin{tabular}{|l|r|r|r|}
\hline & Observed & Expected & Deviation \\
\hline $\begin{array}{l}\text { Online Price discounting time } \\
\text { purchasing }\end{array}$ & 28 & 11 & 3.091 \\
\hline $\begin{array}{l}\text { Online No Price discounting time } \\
\text { purchasing }\end{array}$ & 28 & 8 & 5.000 \\
\hline $\begin{array}{l}\text { Purchase while Price discounting } \\
\text { Preferences }\end{array}$ & 11 & 11 & 0.000 \\
\hline $\begin{array}{l}\text { Purchase while Not Price } \\
\text { discounting Preferences }\end{array}$ & 8 & 8 & 0.000 \\
\hline
\end{tabular}

\begin{tabular}{|l|r|r|r|}
\hline Total Purchase for Discounting & 28 & Chi Sq & df \\
\hline Total Purchase for non-discounting & 28 & 11 & 5.090909091 \\
\hline $\begin{array}{l}\text { Total purchase Preference while } \\
\text { discounting }\end{array}$ & 8 & & Chitest: P Value \\
\hline $\begin{array}{l}\text { Total purchase Preference while } \\
\text { Not discounting }\end{array}$ & 0.151296105 \\
\hline
\end{tabular}

Calculated Value is much higher than the Standard value .05 there for Null Hypothesis Accepted. Price Discounting does not significantly impact consumer behaviour towards online Shopping so giving too much discounting also don't serving purpose.

\section{FINDINGS}

- Gender wise, male are more user of online purchasing compare to female.

- $80 \%$ people opting for online shopping are having income range $10000-30000$

- $72 \%$ people are still preferring physical shopping in patna so only $28 \%$ people are doing online shopping mearly 28 people in sample of 100 .

- $43 \%$ of the online customers are less then $1 \mathrm{yr}$ experice of online shopping mode.

- $54 \%$ of the people are happy \& like to recomedate the online shoopling, so it is gainning popularity \& need to expore further

- Online Buying is popular in Books, Clothing, Cinema/Concert Tickets, Electronics, Gifts \& Accessories item with more than 50\% preference for online shopping by the people else Groceries, Fast food, Cosmetics, Jewellery purchasing still popular by physical purchasing mode.

- Flipkart \& Jabong are the popular site with $42 \%$ \& $35 \%$ people prefere respectively

- Price discounting, Brand accesability \& avaliability are the main attraction of the online shopping as $38 \%$, $32 \%$ \& $24 \%$ preference by people

- Trust, Habit of Purchasing, feeling of the product, payment safty, resistance to get safety while online payment are the reasons for physical purchasing with $24 \%, 26 \%, 17 \%, 10 \%$ \& 19 resdectively eventhough people are familiar \& aware about online shopping.

- Gender is not having any association with mode of purchasing decision eveththough $81 \%$ of the sample are male \& 12 male mail had choosen online mode while only 2 female purchasing online.

- Price discounting not attacting the people for online shopping so there is no association of online purchasing decision \& Price discounting offer

- Reputation of the Website is associated with the selection of website by online user as having strong assotiation.

\section{Conclusion}

Online Shopping is in use in Patna, but still small group of people started doing online shopping.Physical shopping is still in the preferences due to reasons like trust, Habit of Purchasing, feeling of the product, payment safty, resistance to get safety while online payment. Online shopping is getting the attention as $54 \%$ of the people like to refer to their friends.Customers are more likely to tilt towards online 
shopping in sume catergories of products like Books, Clothing, Cinema/Concert Tickets, Electronics, Gifts \& Accessories but still prefer physical shopping for product categories like Groceries, Fast food, Cosmetics, Jewellery may be due to nature of the product \& customer involvement. Price discounting, Brand accesability \& avaliability of the products are the influencial factor for online purchasing due to no physical boundries of shops. There are Advantages \& disadvantages of both the purchasing mode as online purchasing are comfortable, more choice $\&$ cost effective with limitation on customers feeling, mental satisfaction \& security. Physical Purchasing mode give better satisfaction on emotional parameters of customers but limitation of avaiability \& time are there. Reputation \& performance of the online website is important for selection or preference for online selection, like flipkart \& jabong are the popular choice for onlineshopping in patna region.

\section{References}

[1]. Floh, Arne , Koller, Monika, Zauner, Alexander (Apr2013). Taking a deeper look at online reviews: The asymmetric effect of valence intensity on shopping behavior. Journal of Marketing Management. Vol. 29 Issue 5

[2]. Gehrt, Kenneth C.Rajan, Mahesh N.Shainesh, G.Czerwinski, David,O'Brien, Matthew(2012).Emergence of online shopping in India: shopping orientation segments, International Journal of Retail \& Distribution Management., Vol. 40 Issue 10

[3]. Jiang, Ling (Alice, Yang, Zhilin, Minjoon Jun. (2013). Measuring consumer perceptions of online shopping convenience. Journal of Service Management., Vol. 24 Issue 2

[4]. Jifeng Luo,Sulin Ba, Han Zhang. (Dec2012). The Effectiveness Of Online Shopping Characteristics And Well-Designed Websites On Satisfaction, MIS Quarterly., Vol. 36 Issue 4

[5]. Liu, Xia, Burns, Alvin C , Hou, Yingjian(2013).Comparing online and in-store shopping behavior towards luxury goods. International Journal of Retail \& Distribution Management., Vol. 41 Issue 11

[6]. Nirmala, Ratih Puspa,Dewi, Ike Janita. (Apr2012). The Effects of Shopping Orientations, Consumer Innovativeness, Purchase Experience, and Gender on Intention to Shop for Fashion Products Online. Gadjah Mada International Journal of Business. Jan-, Vol. 14 Issue 1

[7]. Wen, Ivan. (Jul-Sep2013). Online Shopping of Travel Products: A Study of Influence of Each Dimension of travelers' Attitudes and the Impact of travelers' Online Shopping Experiences on Their Purchase Intentions, International Journal of Hospitality \& Tourism Administration.Vol. 14 Issue 3.

\section{Consumer towards online shopping}

\section{Annexure}

Questionaire

Please read each question carefully and indicate your response by selecting the most appropriate choice.

\section{Generic Information}

1. Gender: Male $\square$ Female

2. Age: $\square$ rs

3. Education:

4. Occupation:

5. Monthly Income: $10000-20000 \quad \square \quad 20000-30000$ $30000-40000$

40000 \& above

6. Which mode of shopping do you prefer?

Physical store

Both

7. If online for how long have you been shopping online?

2-3 Years

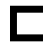

8. If Physical for how long have you been shopping online?

2-3 Years

9. Would you recommend online shopping

to your friends?

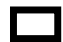

Online

Online
Less than a year
1 to 2 years
More than 3 years

Less than a year

1 to 2 years

More than 3 years

Yes

No

Can't Say 
10. Kindly give your preference Product wise to do your shopping of: (Select only one)

\begin{tabular}{|l|l|l|l|}
\hline & Over The Internet & Retail Store & Over the Phone \\
\hline 1.Groceries & & & \\
\hline 2.Fast Food & & & \\
\hline 3.Books & & & \\
\hline 4.Cosmetics & & & \\
\hline 5.Clothes & & & \\
\hline 6.Cinema/Concert Ticket & & & \\
\hline 7.Jewellery & & & \\
\hline 8.Electronic Goods & & & \\
\hline 9. Gift items & & & \\
\hline 10. Accessories & & & \\
\hline
\end{tabular}

11. Give your Preference of the website select for the onlineshopping

\begin{tabular}{|l|l|}
\hline www.ebay.in & \\
\hline www.olx.in & \\
\hline www.jabong.com & \\
\hline www.amazon.com & \\
\hline www.flipkart.com & \\
\hline Others(specify) & \\
\hline
\end{tabular}

12. Mark the Reasons for shopping online

\begin{tabular}{|l|l|}
\hline Attribute & Mark \\
\hline Price/Discounts & \\
\hline Branding & \\
\hline Time Saving & \\
\hline Accessibility/availability & \\
\hline Brand Consciousness & \\
\hline Friend referrals & \\
\hline
\end{tabular}

11.

12. If you prefer stores, for how long have you been Shopping in physical stores?

2-3 Years

13. Please select the types of stores you visit for Shopping:

Local stores

Less than a year

1 to 2 years

$\square$ More than 3 years

Shopping Malls

Retail store

Flea markets if other please specifies:

14. What are the main reasons for preference of physical stores? (Rank the following in order of importance 1 : most important, 5 least important)

\begin{tabular}{|l|l|l|l|l|l|}
\hline Attribute & 1 & 2 & 3 & 4 & 5 \\
\hline Safety of payment & & & & & \\
\hline Trust of store/brand & & & & & \\
\hline Touch/feel of the product & & & & & \\
\hline Interaction with sales staff & & & & & \\
\hline Overall Experience & & & & & \\
\hline
\end{tabular}

